\title{
Kuzey Kutbu'nda Ortakların Trajedisi Sorununa Çözüm Olarak Küresel Müşterekler Önerisinin Değerlendirilmesi
}

The Evaluation of Global Commons Recommendations as a Solution to the Tragedy of Commons Problem of the North Pole

Abdurrahman TARAKTAŞ 1

Geliş tarihi: 11.05.2019, Kabul tarihi: 05.08.2019, Basım tarihi: 25.10.2019

\section{Öz}

Küresel 1sınmayla birlikte Kuzey Kutbu'ndaki buzulların erimesi, çevresel bir felaket olmasına rağmen, Kuzey Kutbu'nu çevreleyen ülkeler tarafindan ekonomik bir firsat olarak görülmektedir. Kuzey Kutbu ülkeleri diğer ülkelerin Kuzey Kutbu konusunda söz sahibi olmalarına sıcak bakmamaktadırlar. Diğer ülkeler ise, özellikle Avrupa Birliği, Kuzey Kutbu'nun da Antarktika gibi küresel müştereklerden biri olduğunu ve çevresel olumsuz gidişi tersine çevirecek adımların ortak kararlılıkla atılması gerektiğini ileri sürmektedirler. Çalışmada küresel müşterekler kavramı ve ortakların trajedisi sorununu tanımlandıktan sonra Kuzey Kutbu'ndaki politik gelişmeler ve yaşanan değişimin getirdiği sorunlar ele alınmaktadır. Son olarak da Kuzey Kutbu'na getirilen küresel müşterek önerisi değerlendirilmektedir.

Anahtar kelimeler: Kuгey Kutbu, Arktik, Küresel Müsterek, Ortaklarn Trajedisi

JEL Kodlar1: F01, H41, O50

\begin{abstract}
With the global warming, the melting of the glaciers at the North Pole was seen as an economic opportunity by the countries surrounding the North Pole, although it was an environmental disaster. The Arctic countries do not favor the fact that other countries have a say about the North Pole. Other countries, in particular the European Union, have argued that the North Pole is one of the global commons, such as Antarctica, and the steps to reverse the negative environmental advances should be taken with common determination. In the study, after the definition of the global commons and the tragedy of the commons, the political developments in the North Pole and the problems brought about by the changes are discussed. Finally, the global commons proposal for the North Pole is evaluated.
\end{abstract}

Keywords: North Pole, Arctic, Global Commons, Tragedy of Commons

JEL Codes: F01, H41, O50

\footnotetext{
${ }^{1}$ Eskişehir Anadolu Üniversitesi, İktisat Fakültesi Maliye Bölümü, Dr. Öğr. Üyesi, ataraktas@anadolu.edu.tr

https://orcid.org/0000-0003-0649-3291
} 


\section{Giriş}

Kuzey Kutbu bölgesi gezegenin kara yüzeyinin \%15'inden fazlasinı oluşturmasına rağmen, aynı zamanda dört milyon insanla dünyadaki en az nüfuslu bölgelerden de biridir. Yüzyıllar boyunca, dünyanın büyük bir kısmı Kuzey Kutbu'nu sert ve yaşanılmaz bir yer olarak görmüştür. Bununla birlikte, son on yılda bölge, iklim değişikliğinin etkileri nedeniyle eriyen deniz buzunun doğal kaynaklara ve yeni denizcilik yollarına erişimi açması nedeniyle ya da Kuzey Kutbu'nun deniz seviyesinin yükselmesine katkıda bulunmasından dolayı, artan bir uluslararası ilgi görmeye başlamıştır. Kuzey Kutbu'nu çevreleyen ülkeler ${ }^{2}$ tarafindan zengin doğal kaynakları ve yeni ticaret rotası olma potansiyeli sebebiyle ekonomik yönü ön plana alınarak, çevresel önemi göz ardı edilmektedir. İklim değişikliğinin kanıtı ve en sert biçimde yaşandığı noktalardan biri olan Kuzey Kutbu'nun statüsü ve geleceği günümüzde hala net bir biçimde ele alınamamaktadır.

Bu çalışmada, Kuzey Kutbu'nun sadece bir grup devlete ait olmadı̆̆1, çevresel sorunlarla ortak mücadele ve kaynakların adil kullanımının sağlanması için, gün geçtikçe daha fazla taraftar bulan ve daha yüksek sesle ifade edilen, küresel müşterek olarak değerlendirilmesi gerektiği görüşü ele alınmaktadır. Çalışmanın ilk kısmında küresel müşterekler kavramı, kamu maliyesi literatüründeki kamusal mallar tartışması içerisinde önemli bir başlık olan, müşterek mallar ve ortakların trajedisi sorunu konuları bağlamında ele alınmaktadır. İkinci kısımda Kuzey Kutbu'nda yaşanan politik gelişmelere değinilmektedir. Üçüncü kısımda iklim değişikliğinin neden olduğu çevresel ve politik sorunlar değerlendirilmektedir. Dördüncü k1sımda Kuzey Kutbu'nun bir küresel müşterek olarak değerlendirilmesi görüşü ele alınmaktadır. Çalışmanın sonuç kısmında ise tespit ve önerilere yer verilmektedir.

\section{Küresel Müşterekler Kavramı}

Kamusal malların temel iki özelliği olan dışlanamama (herhangi bir kişiyi malın tüketiminden dişlayabilmenin çok pahalı ya da imkânsız olması) ve rakip olmama (mal bir defa üretildiğinde başka bir kişinin malı tüketmesinin ek kaynak maliyetinin sıfır olması) müşterek mallar açısından farklılık göstermektedir. Müşterek malların dışlanamama özelliği yüksek iken tüketimlerinde rekabet söz konusudur. Örneğin, İsviçre Alpleri'ndeki Töbel köyünde köylüler müşterek bir ormana sahiptir ve her köylünün sinırlı miktarda ağaç kesmeye yetkisi vardır. Çünkü ağaç bir kez kesildiğinde artık diğer köylüler için mevcut değildir ve sınırsız ağaç kesilmesi kaynağın geri döndürülemez biçimde yok olmasına neden olabilir (Netting vd. 1981: 68). Bu durum müşterek mallarda "ortakların trajedisi” olarak adlandırılmaktadır

${ }^{2}$ Norveç, Rusya, Amerika Birleşik Devletleri, Kanada, Danimarka, İsveç, Finlandiya ve İzlanda. 
(Hardin, 1968: 1245). Çözüm yolu olarak kullanım hakları konusunda, ortakların kendi aralarında bir anlaşmaya varması veya bir üst merci tarafindan yasal düzenleme yapılması önerilmektedir.

Ortak yararlanılan kaynakların veya alanların bulunduğu müşterekler, çok küçük (bir konut sitesi için otomobil park yeri) veya çok büyük (açı denizler veya uzay) olabilir. Herhangi bir ülkenin yetki alanına girmeyen çok büyük ve ortak yararlanmaya açık kaynaklar ile alanlar uluslararası müşterekler ve küresel müşterekler olarak ikiye ayrilmaktadır (Soroos, 1992: 31). Uluslararası müşterekler, Akdeniz gibi birçok ülke tarafindan paylaşılan alanları ifade etmektedir. Küresel müşterekler ise uzay gibi yer yüzündeki tüm ulusların yasal erişime sahip olduğu alanlardır. İkisi arasındaki temel ayrım uluslararası müştereklerde belirli bir derecede dışlamanın söz konusu olmasidir.

Küresel müşterekler adı verilen kaynaklar ve alanların ortak özellikleri tartışmaya açık olsa da bunlar genel olarak aşağıdaki dört başlikta Özetlenebilir; i) Herkes bu yerleri ve mekanları kullanma özgürlügüne sahiptir. ii) Kimsenin bunları kendine mâl etmesine izin verilmez. iii) Barışç1 amaçlarla kullanım için ayrılmıştır. iv) Bir şekilde uluslararası kurumların kontrolü ve/veya düzenlemesi altındadırlar (Ikeshima, 2015: 112).

Küresel müşterekler, kendilerine erişimin zor olduğu ve içerdikleri kaynakların değeri onları elde etme çabasını haklı çıkaracak seviyede yeterli olmayan, Antarktika, derin denizler ve derin deniz dibi mineral kaynakları, atmosfer ve uzay olarak sayllabilmektedir. Ancak günümüzde teknoloji, ihtiyaca cevap vermek konusunda oldukça başarılıdır. Dolayısıyla S. Buck'a (2017:1) göre, küresel müsstereklerin kırilganlığ1 konusunun, süper güçler arasında günümüzdeki dikkate değer barış çağında ele alınması uygun olacaktır. Çünkü kararlar savaş alanından ziyade müzakere masasında alınmakta, kamuoyunun da kamu politikaları ve yönetim rejimlerinin tasarımı konusundaki tartışmalara geniş çapta katılma olanağı bulunmaktadır.

Yirminci yüzyılın ortalarında Antarktika, toprak talep eden devletlerin hedefi olma tehlikesi altındaydı, ancak günümüzde 1959 tarihli Antarktika Antlaşması ile oluşturulan ve Antarktika Antlaşması Sistemi olarak adlandırılan kendine özgü (sui generis) bir yasal rejim ile karşı karşıyadır. Antarktika Antlaşması Sistemi, kıtanın hem kara hem de çevresindeki deniz alanının istikrarlı kullanımını yönetmektedir. Aynı zamanda, antlaşmaya taraf devletlerin, canlı ve cansız doğal kaynaklar ile çevrenin korunmasina olan ilgilerini somutlaştırmaktadır. Sistem aşağıdaki dört ana ilkeyi temel almaktadır; i) Askeri amaçla değil barışçıl kullanım garantisi. ii) Bilimsel araştırmalar konusunda uluslararası iş birliği özgürlügü. iii) Nükleer testlerin ve radyoaktif atık maddelerin imhasının yasaklanması. iv) Toprak iddiaları ve/veya toprak anlaşmazlıklarının dondurulması (Watts, 1992: 2-4). 
Kanada, Danimarka Krallığı (Grönland ve Faroe Adaları dahil), Norveç, Rusya ve ABD olmak üzere beş ülkenin kıyılarının, İsveç ve Finlandiya'nın topraklarının, İzlanda'nın da küçük bir adasının bulunduğu, Arktik Daire'nin (66 derece 33 dakika kuzey enlem çizgisi) sınırları içerisinde yer alan ve Kuzey Kutbu'nu çevreleyen Arktik Okyanusu, Antarktika kitasına olan benzerlikleri nedeniyle bir küresel müşterek olarak da kabul edilebilir mi? Çalışmanın izleyen kısmında bu soruya yanıt aranmaktadır.

\section{Kuzey Kutbu'ndaki Politik Gelişmeler}

Kuzey Kutbu'nun politik tarihinin, İskandinavya, Rusya ve Kuzey Amerika'nın ilk dönemlerinde kökleri vardır. Kuzey bölgelerinde yaşayan yerli halkların kültürü ve yaşam tarzı, çoğunlukla ticaret ve göçe dayanan sürekli etkileşimli uygulamalara izin vermiştir; Avrupa'nın Yüksek Kuzeyi bu tür sosyal, kültürel ve ekonomik değişimin güzel bir örneğidir. Doğal kaynakları kullanarak gelişen topluluklar olarak: Balıkçılık, avlanma ve ren geyiği sürüleri her zaman Kuzey Kutup yerlilerinin yaşam biçiminin karakteristiği olmuştur (Heininen, 2004: 207).

Ulus-devlet sisteminin kurulmasinın ardından, daha önce var olmayan sabit ulusal sinırlar fikri Kuzey'de de uygulanmaya başlanmıştır. Kuzey Kutbu'ndaki bu gelişme, ren geyikleri ile birlikte mevsimsel olarak seyahat eden ve şimdi sınır geçişi sorunuyla karşı karşıya olan yerli halkların göçebe kabileleri üzerinde çok büyük bir etkiye neden olmuştur. Yeni sınırlar toplulukları ayırmış ve bir şekilde daha önce esnek olan küçük bölgeler statik ve izole hale gelmişlerdir. Bu durum, 19. ve 20. yüzylllar boyunca devam etmiş̧ir. İkinci Dünya Savaş1 ile Kuzey Kutbu daha da derin bir biçimde bölünerek, Rusya (Sovyet bloğu) ve diğerleri (NATO bloğu) biçiminde daha büyük iki blokta birleşmiştir. Siyasi ve askeri olarak karşı karşıya kalsalar da bu bloklar birbirleriyle olan bütün bağları tamamen kesmemişler, kuzeyde çevresel ve bilimsel araştırmalar dahil olmak üzere bazı ortak faaliyetleri sürdürmüşlerdir. Bu bağlar, Sovyetler Birliği'nin dağılmasından sonra filizlenen ve bugün devam eden işbirlikçi çerçevelerin temeli haline gelmiştir (Jegorova, 2013: 126).

Kuzey Kutbu'na olan ilgi, 1980-1990’larda artmaya başlamıştır. İzleyen yıllarda çeşitli uluslararası ve bölgesel kuruluşlar ile yasal çerçeveler şekillenmeye başlamıştır. Çok çeşitli örnekler arasında ortak deniz hukukunun kodlanması ve BM Deniz Hukuku Sözleşmesinin oluşturulmas133; yürürlüğe girdikten beş yil sonra Arktik Konseyi'nin kurulmasına yol açan Arktik Çevre Koruma Stratejisinin (AEPS) 1991 yllinda kabul edilmesi; 1993 yllinda Barents Avrupa-Arktik Konseyi ve Barents Bölge Konseyi'nin kurulması; yerli halkların örgütlerinin oluşumu, Inuit Circumpolar Konseyi

3 1982'de imzalanan UNCLOS, 1994 yllında yürürlüğe girmiştir. 
(1977), Saami Konseyi4 (1992), Rusya Yerli Halkları Birliği Kuzey (1990) ve Gwich'in Uluslararas1 Konseyi (1999) olarak sayılabilir.

Son olarak da 2000'li yillardan itibaren Kuzey Kutbu'na olan ilgi dünya çapında katlanarak artmaya başlamıştır. Bu küresel ilginin arkasındaki neden, öncelikle, küresel ısınmanın etkilerinden kaynaklanan erişilebilirliğin artmasıdır. Küresel ısınmanın Kuzey Kutbu'ndaki fiziksel çevre üzerindeki etkileri zaten kanıtlanmış durumdadır. Kutup buzunun erimesi, Arktik Okyanusu'nda daha önce bölgenin erişilemeyen kısımlarını gemi trafiğine ve kaynak arama çalışmalarına açmaktadır.

Örneğin Ağustos 2007'de, çok uluslu bir ekip tarafindan uzaktan yönlendirilen iki küçük denizaltı Arktik Okyanusu'nun merkezinde dibe indirilmiştir. 4.300 metreye kadar inen mini denizaltı Mir-1 ve Mir-2 ile deniz tabanından su ve tortu örnekleri toplanmıştır. Rus bilim insanları, örneklerin sualtındaki Lomonosov sırtının Rusya'nın kıta sahanlığına doğrudan bağlı olduğu iddiasını ispat edeceğini umuyorlardı. Arktik Okyanusu'nun bu kısmının derinliği ve erişilmezliği göz önüne alındığında bu olay bile başlı başına etkileyiciyken, dalışta çekilmiş fotoğrafların bir Rus bayrağının deniz dibinde denizaltılardan biri tarafindan nazikçe yerleştirildiğini ortaya çıkarması ile durum daha da dikkat çekici hale gelmiştir. Bir metrelik titanyum bayrak direğine bağlı Rus bayrağının fotoğrafları internette dolaşmaya başladığında, manşetler Kuzey Kutbu'nda yeni bir “kapışmanın” yaklaştığ1 uyarılarıyla dolmuştu. Bayrak direğinin paslanmaya karşı dayanıklılığ1, bu özel nesnenin okyanus tabanının dibinde uzun süreli bir varlığa sahip olacağ1 ve dolayısıyla Kuzey Kutbunda Rus varlığını sembolize etmek amacıyla seçildiği iddialarına yol açmıştır. Belki de en sert tepkiyi Kanada Dişişleri Bakanı Peter MacKay, "Onbeşinci yüzyılda değiliz, dünya üzerinde dolaşıp sadece bayraklar dikerek bir bölgeyi talep ediyoruz diyemezsiniz." diyerek vermiştir (Parfitt, 2007).

Arktik Okyanusu'nun konumu ve geleceği ile ilgili iki rakip görüş arasındaki tartışma, 2007 yılında deniz tabanına dikilen Rus bayrağı ile şiddetlenmiştir. Arktik Okyanusu'nun "terra nullius” yani kimseye ait olmayan bir alan, dolayısıyla Antarktika gibi küresel bir müşterek olduğu görüşü, Danimarka tarafindan desteklenen Mayıs 2008 Ilulissat Deklarasyonu ile reddedilmiştir. Deniz Yasası (UNCLOS) temel alınarak, beş kı1 devletinin egemenlik hakları ana hatlarıyla açıklanmıştır. Deklarasyon, Kuzey Kutbu'na artan küresel ilgiye karşı önemli bir önleyici çabay1 ve Arktik Okyanusu'nu yeniden bölgeleştirilmesi kararlılığını simgelemektedir. Arktik Konseyi, hükümetlerarası bir üst kuruluş olarak,

4 Aslen 1956'da Nordic Saami Konseyi olarak kurulmuş, ancak 1992'de bir Rus Saami grubunun dahil edilmesinden sonra yeniden adlandırılmıştır. 
Arktik ve Arktik olmayan taraf ülkelerin çıkarlarına siyasi olarak arabuluculuk yapmada kritik öneme sahip olmaya devam etmektedir.

Ilulissat Bildirgesi'nin arka planı, kısmen bayrak dikilmesi olayına dayanmaktadır. Bu olayı izleyen tarihlerde Avrupa Parlamentosu'ndaki bazı isimler, 1959 Antarktika Antlaşması'na benzer modellenmiş bir Arktik Antlaşması'nın geliştirilmesinin gereğini vurgulamaya başlamışlardır. Başka bir deyişle, Kuzey Kutbu'nun, küresel müşterek olduğunu vurgulayarak kaynaklarının sömürülmesinin durduracak ve bilimsel iş birliği lehine egemenlik politikalarını rafa kaldıracak bir anlaşma istenmektedir. $\mathrm{Bu}$ ise Arktik Beşlisi (Rusya, ABD, Kanada, Norveç ve Danimarka) tarafindan paylaşılan bir yönetim vizyonu değildir. Danimarka girişimi, Kuzey Kutbu'nun küreselleştirilmesi gerektiği fikrine meydan okumak için tasarlanmıştır. Aynı zamanda Greenpeace gibi çevre grupları da yakın zamanda "Kuzey Kutbu'nu kurtarın" sloganiyla, Arktik Okyanusu'nun merkezinin her türlü sömürüden arındırılmış bir küresel müşterek olması gerektiği fikrini ileri sürdükleri bir kampanyayı yürütmeye başlamışlardır (Greenpeace, 2012). Rus Arktik sularında protesto yapan Greenpeace aktivistlerinin gemisi Ekim 2013'te silah zoruyla limana çekilip, aktivistler tutuklandığında, "Kuzey Kutbunu kurtar" kampanyasının egemenlik çıkarlarını korumaya kararlı bir Arktik devleti tarafından iyi karşılanmadığı ise daha net olarak anlaşılmıştır (Dodds, 2014: 118).

Mayıs 2008'de yayınlanan Ilulissat Bildirgesi'nde Arktik Beşlisi; “... Arktik Okyanusu'nun geniş alanlarındaki egemenlik hakları ve yetki alanları nedeniyle, beş kıyı ülkesi gelecekteki olasılıkları ve zorlukları ele almak için eşsiz bir konumdadırlar. Bu bağlamda, 15 ve 16 Ekim 2007 tarihlerinde Oslo'daki toplantıdaki üst düzey temsilcilerimiz arasında da tartışıldığı gibi, Arktik Okyanusu'na kapsamlı bir uluslararası yasal çerçevenin uygulandığını hatırlatıyoruz. Özellikle, Deniz Kanunu, kıta sahanlığının dış sınırlarının belirlenmesi, buzla kaplı alanlar dahil deniz ortamının korunması, seyahat özgürlüğü, bilimsel deniz araştırmaları ve diğer kullanım alanları ile ilgili önemli hak ve yükümlülükler sunmaktadır. Bu yasal çerçeveyle örtüşen taleplerin düzenli bir şekilde yerine getirilmesine bağlı kalmaya kararlıyı. Bu çerçeve, beş kıyı ülkesi ve bu Okyanusun diğer kullanıcıları tarafindan ilgili hükümlerin ulusal düzeyde uygulanması yoluyla, sorumlu yönetim için sağlam bir temel sağlamaktadır. Bu nedenle Arktik Okyanusu'nu yönetmek için yeni bir kapsamlı uluslararası hukuk rejimi geliştirmeye gerek olmadığını görüyoruz. Arktik Okyanusu'ndaki gelişmeleri yakından takip ederek uygun önlemleri almaya devam edeceğiz" vurgusunu yapmışlardır (Danimarka Krallı̆̆1, 2008).

Arktik Konseyi'nin daimî katılımcıları olan diğer üç Arktik devleti (Finlandiya, İzlanda ve İsveç) ile yerli halk örgütleri davet edilmediğinden, Ilulissat Deklarasyonu bir ayrılık yaratmıştır. Bu duruma tepki olarak 
kendisini Arktik Okyanusu kıyı devleti olarak kabul eden İzlanda, izleyen yıllarda Arktik olmayan devletlerle, özellikle Çin ile ilişkilerini derinleştirmiş ve Arktik ile Doğu Asya arasında bir gemi lojistik merkezi olarak kendisini ön plana çıkarmıştır. İsveç, Eylül 2008'de "Arktik için Ortak Endişe" adlı İskandinav Konseyinin himayesinde bir konferans düzenlemiştir. Finlandiya, Avrupa Birliği ile yakın çalışarak ve AB'nin Arktik Konseyi'ndeki kalıcı gözlemci statüsü için adaylığını teşvik etmiş̧ir. Farklı şekillerde, bu üç Arktik devleti, coğrafi bir sahil şeridine sahip olup olmadıklarına bakılmaksızın, Arktik Okyanusu'na olan bağlantılarını vurgulayarak dışlanmalarına cevap vermişlerdir. Arktik Konsey'deki çabaları da ilerleyen yıllarda olumlu sonuçlar vermeye başlamıştır (Dodds, 2014: 121-122).

15 Mayıs 2013'te Arktik Konseyi, tarihi bir hamle yaparak, beş Asya devletine (Çin, Japonya, Hindistan, Güney Kore ve Singapur) uzun süredir bekledikleri gözlemci statüsünü vermiştir. Bu, şimdiye kadar Kuzey'de nispeten kapalı bir alan olarak kabul edilen bir bölge için yeni bir küresel çağın başlangıcını işaret etmektedir. Kuzey Kutbu, ilk olarak Arktik Okyanusu'na kıyısı olan yalnızca beş devletten oluşan bölgesel bir varlıktan, Avrupa ülkeleri ve Güneydoğu Asya'daki ekvatora yakın ülkeleri de içeren çok sayıda bölge ile etkileşim içinde olan daha küresel bir varllğa dönüşmüştür. Bir zamanlar donmuş ve nadiren ele alınan bir bölge şimdi sık sık potansiyel bir "nihai sınır" olarak görülmekte ve dünyanın önde gelen ekonomilerinin ilgisini çekmektedir (Jegorova, 2013: 125). İzleyen yıllarda bu ilginin katlanarak artacağını söylemek mümkündür.

\section{Kuzey Kutbu'ndaki Değişimin Yarattığı Zorluklar}

Kuzey Kutbu'ndaki iklim değişikliği, öncelikle çevresel ve politik olmak üzere karmaşık yeni sorunları beraberinde getirmektedir. Kuzey Kutbu bölgesi, kar, buz ve permafrostun hızla erimesiyle iklim değişikliğinden etkilenmektedir. Bunun sonuçları arasında biyolojik çeşitlilik kaybı, ekosistemlerde bozulma, balık sürülerinin göçü, kıyı erozyonu, arazi kullanım değişiklikleri ve küresel deniz seviyesinin yükselmesi vardır. Değişimin itici güçlerinden bazıları, nüfus artışı ve doğal kaynaklara artan talep, dünya ekonomisinin durumu, değişen ticaret kalıpları, emtia fiyatları veya küresel iklim değişikliği gibi Kuzey Kutbu devletlerinin kontrolü dışındaki küresel mega trendlerdir. Küresel itici güçleri ele almak için uluslararası iş birliğine ihtiyaç vardır, ancak Kuzey Kutbu'ndaki sürdürülebilir kalkınmayı sağlamak söz konusu olduğunda, sorumluluğun büyük bir kısmı, ekonomik faaliyetlerin çoğu topraklarında veya kıyı sularında gerçekleşen ilgili Kuzey Kutbu devletine aittir. Doğal kaynakların çıkarılması için, bölgede balıkçılı̆̆n, deniz taşımacıllğının veya ormancılığın aracılığıyla onlarca yıldır büyük ölçekli ekonomik faaliyetler yürütülmektedir. Bununla birlikte, Kuzey Kutbu ortamının, şu ana kadar nispeten düşük düzeydeki insan faaliyetleri nedeniyle en azından temiz olduğu 
düşünülmektedir. Ancak, insan faaliyetlerindeki artışla (diğer stres yaratıc1 kaynaklarla birlikte) Kuzey Kutbu'nda çevrenin korunması, sürdürülebilir bir kalkınmanın sağlanması ve bölgenin yerel nüfusu için olduğu kadar dünyaya da sağladığı ekosistem faydalarının sürdürülmesi için harekete geçilmesi gerekmektedir (Bock, 2013: 37). Kuzey Kutbu'nda yaşanan değişimin getirdiği zorlukları çevre, doğal kaynaklar, gemi taşımacıllğı, yerel halk ve güvenlik ile ilgili olanlar biçiminde ele alabiliriz.

\section{1. Çevre İle İlgili Sorunlar}

Arktik deniz buzunun günümüzdeki incelmesi ve geri çekilmesi, küresel 1sınmanın en ciddi jeofizik sonuçlarından biridir ve gezegenimizin yüzeyinde büyük bir değişikliğe neden olmaktadır. Durumun endişe verici kısmı, deniz buzunun hem geri çekilme oranının (özellikle yaz aylarında) hem de tüm mevsimlerde incelme oranının çoğu modelin tahminlerini büyük ölçüde aşmasıdır. Diğer bir zorluk da Arktik deniz buzu hacminin kış döneminde, yaz döneminde azaldığı oranın yaklaşık yarısı kadar genişlemekte olduğudur (Wadhams, 2013: 15).

Küresel ortalama sıcaklı̆ı̆n yükselmesi (son yirmi yıldır sürekli olarak hızlanan bir süreçte) zincirleme reaksiyonu tetiklemiş ve Arktik deniz buzu hacminde önemli bir düşüşe yol açmıştır. Eylül 2012'de, 1979'daki uydu gözleminin başlangıcından bu yana en düşük Arktik buz seviyesine sahip olma rekoru kırılmış ve 1979-2000 döneminin ortalama koşullarına kıyasla buz kaplı alanda şaşırtıcı bir \%49’luk azalma görülmüştür (NSIDC, 2012). Daha kalın olan eski buzun yavaşça yerini alan ve kış mevsiminde oluşan daha ince olan ilk yll buzunun izleyen yaz aylarında erimesi ve kırılması çok daha kolaydır. Bu, Arktik Okyanusunu daha uzun nakliye yapılabilir süreler ve daha az gelişmiş gemiler için erişilebilir kılmakta ve aynı zamanda Arktik'te buzsuz yazların yaşanması olasıllğını artırmaktadır. Durum 20082011 yıllarında stabilize edilmiş olmasına rağmen, çok yıllı buz fraksiyonunda devam eden düşüş, yazın sonundaki toplam Arktik buz hacminin azalmaya devam ettiğini göstermektedir. Bu son değişikliklere uyacak şekilde ayarlanan yeni model tahminleri, yaz deniz buzunun 20-30 yil içinde kaybolmasını öngörmektedir (Wang. et al, 2009). Aşağıdaki Şekil 1'de, kryosferde (kar buz örtüsü) meydana gelen güncel değişime yer verilmektedir. 


\section{Şekil 1. Kryosferdeki Erime ve Deniz Ulaşım Yolları}

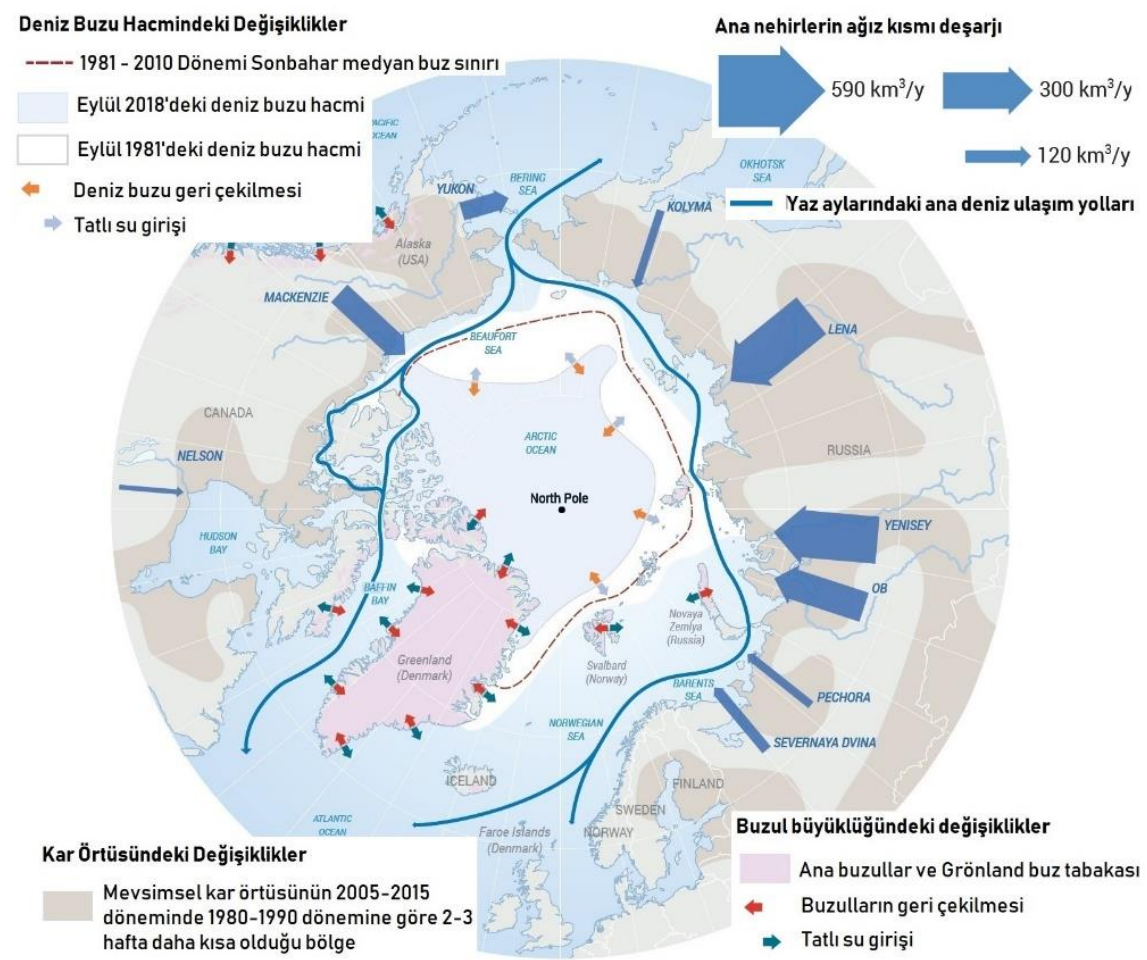

Kaynak: Schoolmeester, T. vd., 2019: 15

Halihazırda Şekil 1'de bu değişikliklerin sonuçları görülmektedir. Yeni geniş açı su alanı yaz aylarında $4-6^{\circ}$ C'ye kadar 1sınmakta, bu da sadece sonbaharda donmanın başlamasını geciktirmekle kalmayıp, aynı zamanda deniz dibini sahanlık alanlarının üzerinde isıtmakta ve denizdeki permafrostları eritmeye yardımcı olmaktadır. Bu eriyiğin bir sonucu, küresel 1sınma potansiyeline sahip metan gazına yol açan, su yatağında hapsolmuş metan hidratların salınımı ve ayrışmasıdır. Bu tür salınımlar Doğu Sibirya Denizi'nde ve Svalbard'da doğrudan gözlemlenmiş (Shakhova vd., 2010:1246) ve küresel atmosferik metan içeriği eğrisi birkaç yıl boyunca sabit kaldıktan sonra küçük bir yükseliş yaşanmıştır. Metan molekülü, sera gazı olarak karbondioksitten 23 kat daha güçlüdür, ancak atmosferde kalma süresi daha azdır (Wadhams, 2013: 16).

\subsection{Doğal Kaynaklar İle İlgili Sorunlar}

Küresel 1sınmanin sonucu olan erime ile birlikte Arktik Okyanusu'nun açılması, denizcilik ve enerji endüstrisinde bir ivme yaratmışır. ABD Jeolojik Etüt Kuruluşu'nun 2008 yllında gerçekleştirdiği bir çalışmaya göre (USGS, 2008), Arktik Okyanusu'nun altında geniş hidrokarbon birikintileri 
(keşfedilmemiş petrolün \%13'ü ve keşfedilmemiş gaz kaynaklarının yaklaşık \%30'unun veya bir başka deyişle dünyanın enerji kaynaklarının \%22'sinin) yattığ1 tahmin edilmektedir (Budzik, 2009: 1). Ancak bu kaynakların çıkarılması pahalı ve muhtemelen çevresel olarak oldukça tehlikelidir. Meksika Körfezi'ndeki 2010 Macondo patlaması ya da Deepwater Horizon petrol sızıntısı felaketi, Arktik Okyanusu'ndan çok daha az zorlu sularda petrol aramanın tehlikelerini ortaya koymaktadır. Ayrıca, 2008'den bu yana dünyadaki ekonomik durgunluk, kaya gazının daha yoğun bir şekilde kullanılması durumunda gelecekteki gaz fiyatlarına ilişkin beklentilerin azalması ve mali konulardaki Rusya ile Norveç arasındaki anlaşmasızlıklar, Barents Denizi'ndeki Shtokman gaz sahası gibi önemli kaynak geliştirme projelerinin yavaşlaması veya ertelenmesiyle sonuçlanmıştır. Ancak, küresel enerji güvenliği endişeleri ve dolaylı olarak Deepwater Horizon'un etkisi sonuçta Kuzey Kutbu petrol ve gaz yataklarına olan ilgiyi yeniden çekecektir. Bu durum, Batı Grönland'daki potansiyel olarak önemli petrol yataklarına dair bulguların açıklanmasıla önem kazanmıştır. BP ve Rosneft, Kara Deniz'in keşfedilmesini hızlandırmayı kabul etmiş olsalar da yasal sorunlar projeyi tehdit etmektedir. Kanada, Rusya, Norveç ve Danimarka, Arktik Okyanusu'nun kıta sahanlığ1 ve buradaki doğal kaynaklar üzerindeki geniş mülkiyet yetkisi konusundaki iddialarını kanıtlamak için jeolojik bilgi sağlamaya çalışmaktadırlar (Yalowitz, 2013: 32). Ülkeler arasındaki bu mülkiyet rekabeti, doğal kaynakların bir süreliğine de olsa korunmasına yardimcı olmaktadir.

Son olarak, Arktik Okyanusu'ndaki erişilebilirliğin artması, yeni balıkçılık alanlarının ortaya çıkması açısından çok önemlidir ve dünya balık pazarındaki durumu etkilemektedir. Kuzey Kutbu denizleri, dünyanın en eski ve en zengin ticari balıkçılık alanlarından bazılarını içermekte ve balıkçılık, Kuzey Kutbu devletlerinin hepsinin olmasa da birçok ekonomisinin önemli bir bölümünü oluşturmaktadır. Balıkçılık, Norveç ve Barents Denizlerinde ve Bering Denizi'nin doğu kısmında özellikle yoğunluk göstermektedir. İklim değişikliğinin Arktik Okyanusu'na komşu bu sularda balık stokları üzerindeki uzun vadeli etkisini tahmin etmek ise zordur. Ancak en muhtemel senaryo, denizler isınırken balık stokların kademeli olarak kuzeye doğru hareket etmesidir. Buz örtüsünün yıl içerisinde daha kısa kalması balık avlanma süresini uzatabilecek ve aşırı avlanmaya sebep olabilecektir. Balık stoklarının azalması kıyı ülkeler arasında sürtüşmelere sebep olabilecektir. Derin denizlerde herhangi bir avlanma kotasinin olmaması da bir diğer önemli problem olarak kendini göstermektedir (Atland, 2012: 210).

\subsection{Gemi Taşımacılı̆̆ı İle İlgili Sorunlar}

İki Arktik nakliye güzergahı üzerinden yolculuk- Rusya'nın Kuzey Denizi Rotası (NSR) ve Kanada'nın Kuzeybatı Geçidi (NWP)- aynı zamanda ticaret 
için gizli bir hazine olarak görülmektedir. Süveyş ve Panama Kanalları üzerinden gerçekleştirilen geleneksel rotalarla karşllaştırıldığında, Arktik Okyanusu'ndan geçmek seyahat mesafesindeki \%20-30'luk bir düşüşe karşıllk gelmektedir (Conley ve Kraut, 2010: 6). Bu durum, daha kısa seyahat süresi, daha az yakıt tüketimi, malların daha hızlı ulaşması ve Avrupa ile Asya pazarlanı arasında alternatif ve daha güvenli (korsanlık tehdidine karşı) bir bağlantı anlamına gelmektedir.

Özellikle, artan hidrokarbon ve mineral madenciliği nedeniyle bölgesel nakliye faaliyeti hızla artmaktadır. Kuzey Kutbu'nda 2004 yılında yaklaşık 6.000 ticari gemi varken bunlardan 1.600 'ü balıkçı gemisiydi. Ayrıca, keşfedilmemiş sularda çalşsan ve işletmecilerinin sınırlı eğitim ve düzenlemelere tabi olduğu turist yolcu gemilerinde de belirgin bir artış bulunmaktadır. Trans-Arktik deniz taşımacilığ yaz aylarında geçerli olmakta ve Avrupa ile Doğu Asya arasındaki ulaşım mesafelerini \%40 azaltabilmektedir. Arktik deniz taşımacıllğındaki bu keskin artışlar, olası etkileri en aza indirmek için acil durum ve kirlilik müdahale prosedürlerinde değişiklik yapılmasını gerektirmektedir. Arktik sularında ele alınması gereken deşarj eksikliği, emisyon ve balast suyu değişim standartları dahil olmak üzere, gemiler için çevresel düzenlemelerde politika boşlukları bulunmaktadır. Ayrıca tüm Arktik bölgesi için kirlilik olaylarının planlanması ve hazırllğı konusunda da bir anlaşma eksikliği söz konusudur.

Arktik Konsey ${ }^{5}$, bugüne kadar Kuzey Kutbu'ndaki insani gelişmelerin yanı sıra iklim değişikliği ile ilgili de başarılı raporlar üretmeyi başarmışır. Bölgedeki uluslararası arama ve kurtarma çalışmalarındaki koordinasyon sıkıntısına dikkat çekmek amacıyla 2009 yllında, Arktik Deniz Taşımacilı̆̆ Değerlendirmesi'ni yayınlamıştır. Nunavut'taki kurulan yeni madenlerdeki katlanarak gerçekleşen büyümenin, o bölgede önemli ölçüde gemi trafiğinin artması potansiyelini beraberinde getirdiği görülmektedir. Her yaz karaya vuran tanker ve yolcu gemisi sayısı, Kuzeybatı Pasajı'ndaki Arktik sularının sadece \%10'unun işaretlenip haritalandırılması nedeniyle büyük bir riske işaret etmektedir. $\mathrm{Bu}$ sadece gemi yolculuğunun güvencesiz bir operasyondan ibaret olmasını sağlamakla kalmamakta, insanların hayatlarını tehlikeye atmakta ve bir petrol sızıntısı olursa kıyı ekosistemleri için potansiyel bir tehdit oluşturmaktadır (Arctic Council, 2009).

\subsection{Yerel Halkla İlgili Sorunlar}

Alaska, Kuzey Kanada, Grönland, Norveç, Finlandiya, İsveç ve Rusya'da düzinelerce dil konuşan 30'dan fazla farklı yerli halk topluluğu da dahil

58 Arktik ülkesinin ve 6 yerel topluluk temsilciliğinin daimî üyeler, Almanya, Hollanda, Polonya, İngiltere, Fransa, İspanya, Çin, Hindistan, İtalya, Japonya, Güney Kore, Singapur ve İsviçre'nin ise gözlemci üye statüsünde yer aldığı hükümetler arası forum. 
olmak üzere 4 milyon insan Kuzey Kutbu'nda yaşamaktadır. Kuzey Kutbu halkları ve Kuzey Kutbu ülkeleri arasındaki çeşitliliği göz önünde bulundurmak önemlidir. Kuzey Kutbu genellikle tekdüze bir bölge olarak düşünülse de çok sayıda yerel ve bölgesel unsur bulunmaktadır. Ayrıca, yönetişim yapıları değiştirilip geliştirildikçe, yerli halkların çıkarlarının marjinalleştirilmesini engellemek için "paydaş" yerine "hak sahipleri" tanımının kullanılması da önemlidir. Kuzey Kutup yerlileri, deniz, tatlı su ve kara kaynaklı yaşam kaynaklarına bağlı olarak bin yıl boyunca hayatta kalmışlardır. Coğrafi bir yere dayanan ve tarihsel bir miras olarak nesiller arası aktarılan "geleneksel ekolojik bilgi", günümüzde bu grupların birçoğunun dili ve kültürüyle birlikte kaybolmak üzeredir. Kuzey Kutbu'ndaki çevresel ve iklimsel değişiminin Kuzey Kutbu topluluklarının sosyo-ekonomik yapısı üzerinde doğrudan bir etkisi bulunmaktadır. Geleneksel geçim kaynakları olan avlanma ve balık avcılığı, iklim değişikliğinden kaynaklanan etkilerden olumsuz etkilediği için (özellikle kutup ayıları, foklar, balinalar ve bazı balık türleri deniz buzuna bağlı olduklarından) tehdit altındadır. Dahası Permafrost'un çözülmesinin toplum altyapısı için potansiyel olarak yaygın olumsuz etkileri söz konusudur. Kısacası, yerli halklar artık iklim değişikliğinden küreselleşmeye kadar değişen çeşitli büyük risklerle karşı karşıyadırlar. Bu tehditlerin birçoğu, yerli olmayan yerel nüfusa da yayılmaktadır (Cavalieri vd., 2013: 285-286).

Yerel halkın gördüğü zararın giderilmesi için iş birliği olanaklarının araştırılması ve artırılması gerekmektedir. Arktik Konseyi 1996'da kurulmasindan itibaren, Kuzey Kutbu devletleri ile yerel halk arasinda işbirliğini ve koordinasyonu teşvik eden üst düzey bir forum olarak faaliyet göstermektedir. Özellikle çevrenin korunması ve sürdürülebilir kalkınma konusundaki ciddi meseleleri ele almanın gereği neticesinde, bir grup yerel halk lideri ve ulusal politika yapıcı tarafindan birkaç yıl süren zorlayıcı diplomatik çalışmanın ürünü olarak ortaya çıkmıştır. Arktik Konsey’ini diğer bölgesel, çok taraflı örgütlerden farklı kılan, daha kapsayıcı bir karar alma süreci ve yönetişim olanağı sağlamak amacıyla, yerli grupların daimî üyeler olarak dahil edilmesidir.

\subsection{Güvenlik İle İlgili Sorunlar}

Arktik buzunun erimesiyle, ulaşılabilir hale gelen doğal kaynakları çıkarabilmek için, ülkelerin Arktik Okyanusu'ndaki kıta sahanlıklarını genişletme gayretleri uluslararası politikada güç gösterisi ve gerilimlere sebep olabilecektir. Bu tür çıkar çatışmaları günümüzde, Arktik kıyı devletlerinin Arktik Konseyi, Birleşmiş Milletler Deniz Hukuku Sözleşmesi ve diplomasi aracılığılla kurumsal çözümlere bağlılı̆̆1 1şı̆̆ında giderilmektedir. Bununla birlikte Arktik devletlerin arasındaki gerginliğin artmasıyla bölgede yavaş yavaş askeri faaliyetlerin de arttı̆̆1 görülmektedir. 
Bazı ülkelerin Arktik Okyanusu'nda hayati çıkarları bulunmaktadır. Örneğin Rusya gelecekteki ekonomik gelişimini, kuzeydeki enerji ve maden rezervlerine bağlı görmektedir. Rusya'nın ortaya koyduğu Arktik stratejisi, kuzeyindeki kaynak gelişimini güvence altına almaya ve korumaya odaklanmaktadır. Rusya ve Kanada, sırasıyla Kuzeydoğu ve Kuzeybatı deniz geçitleri üzerinde ulusal hak sahibi olduklarını iddia etmekteler ve yakın bölgelerindeki uluslararası deniz taşımacıllğının büyümesini izlemektedirler. Bölgedeki deniz operasyonlarının yanı sıra, Arktik Okyanusu'nda Amerika Birleşik Devletleri'nin çıkarları Alaska'nın konumundan kaynaklanmaktadır. Danimarka ve Norveç'in de Arktik Okyanusuyla ilgili önemli beklentileri mevcuttur (Yalowitz, 2013:31-32). Bölge, ticari ve ekonomik potansiyeli ile pek çok ülkeyi kendisine çekmektedir.

Askeri güç, zaman ilerledikçe bölgedeki yerini almaya devam etse de sadece belirli bir dereceye kadar kaynakların kullanılabilirliğini belirlemektedir. En olası senaryoda, yeni sinırları tanımlayacak olan ise bilimdir (Zellen, 2009). Her bir Arktik devletinin açık deniz alanının dış sınırları, deniz altı haritalama ve üzerinde anlaşmaya varılan yasal prosedürler ile belirlendiğinden kesin değildir. Dolayısıyla Kuzey Kutbu kıta sahanındaki sınırlar ve mülkiyet alanı üzerindeki belirsizlik ve anlaşmazlıklar, devletlerarası anlaşmalar yoluyla giderilebilmektedir. Murmansk'ta 15 Eylül 2010'da imzalanan Barents Denizi ve Arktik Okyanusu'ndaki sınırlandırma ve iş birliği konusundaki Norveç-Rus anlaşması, Kuzey Kutup Bölgesi'ndeki diğer sınırlandırmalar için bir örnek teşkil etmektedir. Bununla birlikte, Kuzey Kutbu'ndaki uzun vadeli çatışma potansiyelini, Kuzey Kutbu kıyı devletleri ile Arktik Konseyi’nin kalan üç üyesi (İzlanda, İsveç ve Finlandiya) arasındaki uyuşmazlık ve belki de daha problemli bir şekilde Arktik ve Arktik olmayan devletler arasındaki uyuşmazlık bağlamında ele almak gerekmektedir. Çin gibi bir diş aktörün ticari, askeri veya başka amaçlar için bölgede aniden önemli bir varlık göstermesi, Kuzey Kutbu devletler topluluğu ile potansiyel sürtüşmelere yol açabilecektir (Howard, 2009). Ayrıca üçüncü taraf aktörlerin tartışmalı alanlarda kaynakların keşfedilmesi veya çıarılması faaliyetlerine dahil edilmesi de devletlerarası ilişkiler üzerinde dengesizleştirici bir etkiye sahip olabilecektir (Atland, 2012: 209). Güvenlik sorunu Kuzey Kutbu bölgesi açısından önemli bir tehdit olarak varlığını sürdürse de ülkeler açısından diplomasi halen ilk seçenek olarak tercih edilmektedir.

\section{Kuzey Kutbu İçin Küresel Müşterekler Önerisi}

Kuzey Kutbu'nda kıyısı olmayan devletlerden gelen açıklamalar, Kuzey Kutbu'nun küresel müşterek ya da en azından küresel bir ilgi alanı olduğu fikrini uzun zamandır ifade etmektedir. Küresel müştereğin en açık ve en çarpıc1 ifadelerinden biri Arktik'i "insanlığın ortak mirası" olarak etiketlemektir (Shackelford, 2009). Kuzey Kutbu'nun küresel müşterek 
olarak ele alınması fikrini en yüksek makamdan Avrupa Birliği ifade etmektedir. Yüksek Temsilci / Başkan Yardımcısı Mogherini (2017) Kuzey Kutbu'nu şöyle tanımlamaktadır; “... Bazen biliyorsunuz, biz Avrupalılar Kuzey Kutbu'nun kıtamızın kuzey sınırı olduğunu düşünüyoruz. Fakat, aslında, Kuzey Kutbu'nun bir sınırdan çok dünyaya açılan gerçek bir geçit haline geldiğine inanıyorum. Kuzey Kutbu sadece dağınık hayvanların olduğu beyaz bir yüzey değildir. Üniversiteler, yenilikçi teknolojiler, sürdürülebilir kalkınma için bir mekandır. Artık Avrupa için bir sınır değil, bir geçit ve kıtalar arasındaki bir kavşaktır. Burası bizim buluşma yerimizdir. Bu yüzden onu korumak bizim ortak sorumluluğumuzdur. Bu bizim ortak iyiliğimizedir ve sadece halkı için değil aynı zamanda kendimiz ve tüm dünya için, yerel ve küresel olarak korumak konusunda ortak bir sorumluluğumuz vardir".

Erişilebilirlikteki artış doğal olarak yalnızca Arktik Okyanusu ile doğrudan bağlantısı olan kıyı devletleriyle değil, aynı zamanda Arktik Daire enleminden daha güneyde bulunan "dışardakiler" olarak adlandırılan ülkeler için de ilgi çekicidir. Önceden erişilemeyen bir okyanusun bir asırdan daha kısa sürede gezilebilir sular olacağının tahmin edilmesi iklim değissiminin etkilerini boyutunu ortaya koyan görülmemiş bir durumdur (Prestrud, 2007: 11, 91). Gezegenimizdeki 1ssız bir kara parçasını keşfetmeye neredeyse eşit bir biçimde, kıt kaynaklar ve derinleşen ekonomik bağların dünyasında, Arktik'te sınırı olmayanların bile vadettiği fırsatlarla ilgilenmesi oldukça anlaşılabilir bir durumdur. Bu üçüncü ülkeler Arktik Okyanusunun insanlığın mirası olduğunu iddia etmekte (Gautam, 2011: 9, Jakobson, 2010: 9-10) ve bölgeye eşit erişim ve haklar için itirazda bulunmaktadır. Önerdikleri seçeneklerden biri "merkez Arktik havzasındaki mülkiyet haklarının dondurulması" ile yönetim ve iş birliğinin kolaylaştırılmasına odaklanılmasidir (Young, 2009: 81).

Genel olarak, akademinin zaten kırmızı bayrağı yükselmiş ve Arktik iklim değişikliğinin yağış patikalarının değişmesine, deniz buzu hacminin ve kalınlığının azalmasına, biyolojik çeşitliliğin azalmasına, ekosistemlerin bozulmasına, kuşların göç etmesine neden olabileceği konusunda uyarıda bulunmuştur. Zamanla istilacı balık türlerinin etkisiyle Kuzey Kutbu balık stoku türlerinin kompozisyonunu da değişebilecektir. Deniz buzunun artık daha az desteklemesi sonucunda toprak buzulunun erimesi ile k1y1 erozyonunun artabileceği ve altyapının genişlemesi uygulamaları da devam ederse büyük ölçekli arazi kullanım değişikliklerinin gerçekleşebileceği belirtilmektedir. Politika yapıcılar, Kuzey Kutbu ekosistemlerinde büyük değişikliklere yol açan iklim değişikliğinin, yalnızca Kuzey Kutbu'nda değil, çevresel kendini yenileme sistemlerinde geri döndürülemez tahribat yaratarak küresel olarak hissedilecek sonuçlar doğurabileceği konusunda uyarılmaktadırlar (Bock, 2013: 42). Bu durum Arktik özelinde bir "ortakların trajedisinin” yaşanma olasılığının yüksek olduğunu göstermektedir. 
Son olaylar, Kuzey Kutbu'nda kıyısı olan devletler ile diğer paydaşların Arktik Okyanusu ile olan ilişkilerini temelde yeniden değerlendirdiklerini göstermektedir. Arktik Okyanusu'nun hâkim yönetimi, Antarktika ve Güney Okyanusu'ndan oldukça farklı bir durumdadır. Arktik Okyanusu 1959 Antarktika Antlaşmasi'na eşdeğer biçimde bir küresel müşterek statüsünde değildir. Küresel müştereklerin yönetimi, çıkar çatışmalarının engellenmesi ve yönetilecek kaynakların verimli kullanılmasını sağlamak için sıkı normların yanı sıra yeterli teşvikleri de sunan genellikle uluslararası ve uluslarüstü çoğulcu tüzel kişilikler gerektirmektedir. Arktik Okyanusunda ise kaynakların aşırı kullanımını ve çevresel zararları engellemeye yönelik bu tür bir yönetim yapısının oluşturulması oldukça güç görülmektedir. Önümüzdeki yıllarda, iklim değişikliğinin etkisi bölge genelinde daha fazla hissedildikçe, Kuzey Kutbu ülkeleri arasındaki egemenlik ve güvenlik sorunları da artacaktır.

\section{Sonuç}

Kuzey Kutbu, küresel müşterek ve insanlığın ortak bir mirası olarak görülmeyi hak etmektedir. Kuzey Kutbu şu anda beş Arktik kıyı devleti ve bazı gözlemci devletler ile yerel halk örgütlerinin yer aldığ Arktik Konsey biçimindeki bölünmüş bir yönetim yapısına sahiptir. Söz konusu devletler kendi ulusal çıkarları peşinde koşmakta, kaynakların büyük kısmını ele geçirmek üzere egemenlik alanlarını genişletmek amacıyla mücadele vermekte ve aralarında da önemli anlaşmazlıklar bulunmaktadır. Kuzey Kutbu'nun nadir ekolojisini koruma kararll1kkları sadece sözde kalmakta ve uygulama konusunda herhangi bir adım atmamaktadırlar. Bölge ilerleyen yıllarda çevresel sorunların yanı sıra askeri gerginliklere de sahne olma potansiyeli taşımaktadır.

Ancak Kuzey Kutbu bir küresel müşterek olarak tanınan Antarktika'dan önemli farklılıklar da içermektedir. Birincisi, Antarktika okyanusla çevrili bir kıta ve Kuzey Kutbu kıtalarla çevrili bir deniz bölgesidir. İkincisi, Antarktika buzu mevsimsel, çoğunlukla bir yıllıktır, Arktik buzu uzun sürelidir ve mevsim ne olursa olsun Arktik Okyanusunun önemli bir bölümünü kaplar. Üçüncüsü, Kuzey Kutbu kıta sahanllğı son derece sığ derinliğe ve kayda değer uzunluğa sahiptir ve Antarktika kıta sahanlı̆̆, uzunluk bakımından farklılık göstermese de dünyadaki en derin kıta sahanlı̆ından biridir. Son olarak, Arktik Okyanusu'nun bölgelerinde tarihsel olarak Kuzey'in yerli halklarının temsilcileri yaşarken, Antarktika'da yerli bir nüfus yoktur. Dolayisıyla bu farkll1ıklar Kuzey Kutbu'nun küresel müştereklerden sayılmasını zorlaştırmaktadır. Çünkü bölgede egemenlik sahibi devletler ve yerel halklar bulunmakta, doğal kaynaklara ulaşmak nispeten daha düşük maliyetle olmaktadır. Ayrıca stratejik konumu gemi taşımacilığı firsatları da sunmaktadır.

Ulusal hükümetler, uluslararası kurumlar ve devlet dişı aktörler Kuzey Kutbu yönetimine farklı yaklaşımlar getirirken, bu bölgenin karşılaştığ 
çevresel, ekonomik, sosyo-kültürel ve jeopolitik zorlukları ele almak için uyumlu ve kapsamlı bir yaklaşım gerekmektedir. Çevresel konularının ön planda tutulduğu anlaşmalarla kaynakların aşırı tüketiminin önüne geçilmeye çalışılmalıdır. Dış paydaşlara özellikle Avrupa Birliğı’ne yönetimde söz hakkı taninmalidır.

Gerçekte ihtiyaç duyulan şey, bu bölgenin karmaşık yapısını ve ilgili tüm konuları açık ve tutarlı bir şekilde anlamaktır. Sonuçta, Kuzey Kutbu hem daha küçük bölgeler kümesi hem de kendine özgü bir bölgedir. Farkl1 seviyelerde dinamik ve işleyen karmaşık bir varlıktır ve izole olduğu dünyayla da ondan farklı olduğu gibi benzerlikler de taşır. Küresel ısınma, Dünyanın her kössesinde belirgindir, ancak doğası gereği iklim değişikliğinin etkileri en uç şekilde Kuzey Kutbu'nda izlenebilir. Belirli iklim ve ekolojik koşulları nedeniyle Kuzey Kutbu'nun tasarlanması gereken özel kurallara ihtiyacı vardır. Kuzey Kutbu'nu küresel yapan şeyin, onu dünyanın diğer bölgelerinden biraz daha farklı kıldığı söylenebilir.

Bilimsel araştırmalar ve bunların küresel kamuoyu ile etkili bir biçimde paylaşımı kutup bölgelerinin korunması ve sürdürülebilirliği için önemlidir. Bununla birlikte, eğitim, sosyal yardım ve iletişim stratejileri halkın bu bölgeye yönelik ilgisini ve bilimsel bilincini geliştirmek için geliştirilmelidir. Dünya halklarının çevre hakkında temel bir anlayışa sahip olması, çevrenin korunması ve restorasyonu için politik karar alıcılar üzerinde bir etki yaratabilecektir.

Ortakların trajedisi sorunu küresel çevre politikaları alanında sıkça rastlanılan bir durumdur. Kavram, sağladıkları bireysel yararı en üst seviyeye çıkarmaya çalışıken, aşırı kullanımlarının neden olduğu zarar ve maliyetleri göz ardı eden ortakların, müşterek alan veya malların zarar görmesi ve tükenmesi neticesinde toplu bir biçimde zarar etmeleri ve tüketimden mahrum kalmaları durumunu ifade etmektedir. Kisa vadeli ve dar kapsamlı ulusal çıkarlarını her şeyin önünde gören devletler kararlarının uzun vadeli ve tüm dünyayı ilgilendirebilecek seviyede geniş kapsamlı çevresel etkilerini ikinci plana atmaktadırlar. Bunun açık bir örneğini, sınırlı bir kaynak olan petrol çıkarılması konusu oluşturulmaktadır. Petrolün bir devlete getirebileceği ekonomik faydalar o kadar büyüktür ki, olası çevresel zararları konusunda tereddüt gösterilmemektedir. Bir petrol sızıntısının, hassas dengeler üzerine kurulu bir ekosistemi içeren dünyadaki bozulmamış nadir bir ortam olan Kuzey Kutbu'nu yok edebileceği gerçeğine rağmen geri adım atılmamaktadır. Çoğu zaman bir devletin bencilce emellerinin en kötü sonuçlarına, kendinden uzakta olan ülkeler de maruz kalmaktadırlar. Sonuç olarak, küresel müştereklerin bozulmalarını önlemek için sıkı bir düzenleme ve yönetime ihtiyaçları vardır, çünkü sömürü hızlı, kısa vadeli faydalar getirse de uzun vadeli etkilerin herkes için olumsuz olacağ kesindir. 


\section{Kaynakça}

Arctic Council (2009). Arctic Marine Shipping Assessment 2009 report . Protecting the Arctic Marine Environment (PAME) working group of the Arctic Council, Akureyri. http://www.pame.is/amsa/amsa-2009-report (Son Erişim: 01.05.2019)

Atland, K. (2012). "The security implications of climate change in the Arctic Ocean". Environmental security in the Arctic Ocean. Springer, Dordrecht.

Bock, N. (2013). "Sustainable development considerations in the Arctic". In Environmental security in the Arctic Ocean (ss. 37-57). Springer, Dordrecht.

Buck, S. J. (2017). The global commons: an introduction. Routledge.

Budzik, P. (2009). Arctic oil and natural gas potential. US Energy Information Administration, Office of Integrated Analysis and Forecasting, Oil and Gas Division.

Cavalieri, S., \& Kraemer, R. A. (2013). "Transatlantic policy options to address the rapidly changing Arctic". In Environmental Security in the Arctic Ocean (ss. 281-293). Springer, Dordrecht.

Danimarka Kralliğ1, The Ilulissat Declaration. http://www.oceanlaw.org/downloads/arctic/Ilulissat_Declaration .pdf (Son Erişim: 01.05.2019)

Dodds, K. (2014). 'Squaring the Circle: The Arctic States,'Law of the Sea,' and the Arctic Ocean". Eurasia Border Review, 5(1), 113-124.

Greenpeace. (2012). Save the Arctic Campaign - Greenpeace International https://www.greenpeace.org/international/act/save-the-arctic/

Hardin, G. (1968). "The tragedy of the commons". Science, 162(3859), 12431248.

Heininen, L. (2004). Circumpolar international relations and geopolitics. Arctic human development report, 207-225.

Howard, R. (2009). "The Arctic gold rush: the new race for tomorrow's natural resources". Continum, London

Ikeshima, T. (2015). Should Japan's Arctic Policy be Based on the Assumption that the Arctic Ocean is a Global Commons?. In Waseda Global Forum (No. 12, ss. 109-150).

Jegorova, N. (2013). Regionalism \& Globalisation: The Case of the Arctic. Arctic Yearbook, 125-141. 
Mogherini, F. (2017). Speech by the High Representative / Vice-President Federica Mogherini at the High Level Arctic Event. https:/ / eeas.europa.eu/arctic-policy/eu-arctic-

policy/28274/speech-high-representative-vice-president-federicamogherini-high-level-arctic-event_en (Son Erişim: 01.05.2019)

Netting, R. M., \& Netting, R. M. (1981). Balancing on an Alp: ecological change and continuity in a Swiss mountain community. CUP Archive.

NSIDC. (2012). Poles apart: A record-breaking summer and winter. Arctic Sea Ice News \& Analysis. http://nsidc.org/arcticseaicenews/2012/10/poles-apart-a-recordbreaking-summer-and-winter/ (Son Erişim: 01.05.2019)

Parfitt, T. (2007). Russia plants flag on North Pole seabed. The Guardian

Schoolmeester, T., Gjerdi, H.L., Crump, J., Alfthan, B., Fabres, J., Johnsen, K., Puikkonen, L., Kurvits, T. and Baker, E., 2019. Global Linkages - A graphic look at the changing Arctic. UN Environment and GRID Arendal, Nairobi and Arendal. www.grida.no

Shakhova, N., Semiletov, I., Salyuk, A., Yusupov, V., Kosmach, D., \& Gustafsson, Ö. (2010). "Extensive methane venting to the atmosphere from sediments of the East Siberian Arctic Shelf". Science, 327(5970), 1246-1250.

Soroos, M. S. (1992). "Conflict in the Use and Management of International Commons". Perspectives on Environmental Conflict and International Politics, London: Pinter Publishers, 31-43.

Wadhams, P. (2013). "Diminishing sea-ice extent and thickness in the Arctic ocean". In Environmental Security in the Arctic Ocean (ss. 15-30). Springer, Dordrecht.

Wang, M., \& Overland, J. E. (2009). "A sea ice free summer Arctic within 30 years?". Geophysical research letters, 36(7).

Watts, A. (1992). International law and the Antarctic treaty system (Vol. 11). Cambridge University Press.

Yalowitz, K. S. (2013). "Arctic Climate Change: Security Challenges and Stewardship Opportunities". In Environmental Security in the Arctic Ocean (pp. 31-36). Springer, Dordrecht.

Zellen, BS. (2009). Arctic doom, Arctic boom: the geopolitics of climate change in the Arctic. Praeger, Santa Barbara

Shackelford, S. J. (2009). The tragedy of the common heritage of mankind. Stan. Envtl. LJ, 28, 109. 
USGS. (2008). Circum-Arctic Resource Appraisal: Estimates of Undiscovered Oil and Gas North of the Arctic Circle. https://pubs.usgs.gov/fs/2008/3049/fs2008-3049.pdf (Son Erişim: 01.05.2019) 